\title{
Transcriptional regulation of $C D 4$ gene expression in porcine kidney epithelial cells by virus-like double-stranded RNA and DNA methyltransferase inhibitor
}

\author{
X.S. Wang ${ }^{1}$, H. Ao ${ }^{2}$, L.W. Zhai ${ }^{1}$, L.J. Bai ${ }^{2}$, W.Y. He ${ }^{3}$, C.D. Wang ${ }^{1}$, Y. Yu ${ }^{1}$ \\ ${ }^{1}$ National Engineering Laboratory for Animal Breeding, \\ Key Laboratory of Agricultural Animal Genetics, Breeding and Reproduction, \\ Ministry of Agriculture of China, Department of Animal Breeding and Genetics, \\ College of Animal Sciences and Technology, China Agricultural University, \\ Beijing, China \\ ${ }^{2}$ State Key Laboratory for Animal Nutrition, \\ Key Laboratory for Domestic Animal Genetic Resources and Breeding of the \\ Ministry of Agriculture of China, Institute of Animal Science, \\ Chinese Academy of Agricultural Sciences \\ ${ }^{3}$ State Key Laboratory of Agrobiotechnology, \\ Department of Microbiology and Immunology, \\ College of Veterinary Medicine, China Agricultural University, Beijing, China \\ Corresponding authors: C.D. Wang / Y. Yu \\ E-mail:wangchuduan@qq.com / yuying@cau.edu.cn
}

Genet. Mol. Res. 13 (2): 3346-3355 (2014)

Received January 25, 2013

Accepted November 18, 2013

Published April 29, 2014

DOI http://dx.doi.org/10.4238/2014.April.29.13

ABSTRACT. The effects of virus-like double-stranded RNA (dsRNA, PolyI:C) and DNA methyltransferase inhibitor (Aza-CdR) on CD4 gene expression were investigated in a porcine kidney cell line (PK15). We found that expression levels of $T L R 3$ and $I F N \alpha$ were significantly upregulated by PolyI:C, compared to the untreated PK15 cells, which shows that PolyI:C successfully mimics viral infection in PK15 cells. We 
also found that PolyI:C $(10 \mu \mathrm{g} / \mathrm{ml})$ and/or Aza-CdR $(5 \mu \mathrm{M})$ significantly induces DNA demethylation of porcine $C D 4$, promoting the binding of $\mathrm{NF}-\kappa \mathrm{B}$ to the $\mathrm{CpG}$ site on the $C D 4$ promoter and activating expression of $C D 4$. These data help clarify the regulatory mechanism of DNA methylation of the CD4 gene in non-immune cell response to virus replication. Further study is warranted to identify $C D 4$ gene expression regulated by DNA methylation and live virus infection.

Key words: Porcine kidney epithelial cells; $C D 4$; NF-кB; EMSA; DNA methylation

\section{INTRODUCTION}

Classical swine fever (CSF) is caused by the classical swine fever virus (CSFV) and is a highly contagious disease of pigs. CSF is endemic in Asia, Central and South America, and parts of Europe and Africa. Pinpoint hemorrhages on the porcine kidneys are characteristic of CSF (http://www.aphis.usda.gov). Eradicating CSF is problem because the molecular mechanism of pigs resistant to CSFV infection remains unclear (Gladue et al., 2010).

The active component of a viral infection that stimulates antiviral activities appears to be double-stranded RNA (dsRNA) (Heitmeier et al., 1998; Majde, 2000), which is produced in infected pig cells during the replication of CSFV (Bauhofer et al., 2005). Synthetic polyinosinic:polycytidylic acid (PolyI:C) is structurally similar to the natural virus dsRNA and is a common artificial immunostimulant to induce the syndrome of viral diseases (Heitmeier et al., 1998; de La Motte et al., 1999; Majde, 2000). PolyI:C is known to be recognized by toll-like receptor 3 (TLR3) and is best known as an inducer of interferon (IFN), which plays a significant role in viral recognition and activation of innate immunity (Heitmeier et al., 1998; Tissari et al., 2005; Stowell et al., 2009; Hüsser et al., 2011). Thus, PolyI:C is considered a viral-associated dsRNA to mimic viral infection in the study of the immune response of host cells (Heitmeier et al., 1998; Majde, 2000; Geiss et al., 2001; Harris et al., 2013).

Recent studies identified that during virus replication, immune-related genes of the host cells were regulated by DNA methylation (Flanagan, 2007). DNA methylation is a major epigenetic mechanism of gene silencing, and aberrant DNA methylation variations are specific to the immune system and influence cellular status. The cytidine analog 5-aza-2'-deoxycytidine (Aza-CdR) can hypomethylate DNA by inhibiting DNA methyltransferase (Patel et al., 2010). More recently, Luo et al. (2011) reported that promoter demethylation and upregulation of cluster of differentiation 4 gene (CD4) was induced by Marek's disease virus. The regulation mechanism of DNA demethylation in the $C D 4$ gene in swine cells remains unclear. The purpose of the study was to identify and validate the biofunctions and the regulatory effects of DNA methyltransferase inhibitor on the porcine CD4 gene in porcine kidney epithelial cell line (PK15) transfected with viral-associated dsRNA.

\section{MATERIAL AND METHODS}

\section{Cell culture and treatment}

Porcine kidney cell line (PK15) was grown in Dulbecco's modified Eagle medium 
(DMEM) (Invitrogen, Carlsbad, CA, USA) containing 10\% heat-inactivated fetal bovine serum (FBS) (HyClone, Logan, UT), $100 \mathrm{U} / \mathrm{mL}$ penicillin and $100 \mu \mathrm{g} / \mathrm{mL}$ streptomycin (Invitrogen) at $37^{\circ} \mathrm{C}$ with $5 \% \mathrm{CO}_{2}$. PolyI:C $(10 \mu \mathrm{g} / \mathrm{mL}$; polyinosinic:polycytidylic acid; SigmaAldrich, Shanghai Trading Co., Ltd) was added to the culture medium after the cells were serum-starved for $2 \mathrm{~h}$. Four hours later, different concentrations of Aza-CdR $(0.1,1,5 \mu \mathrm{M}$; Sigma-Aldrich, St. Louis, MO, USA) were added.

\section{Extraction and bisulfite treatment of genomic DNA}

Genomic DNA was extracted from the PK15 cells using the Wizard Genomic DNA Purification kit (Promega, USA). DNA concentration and quality were measured with the NanoDropTM ND-2000c Spectrophotometer (Thermo Scientific, Inc., USA). Sodium bisulfite conversion of $1 \mu \mathrm{g}$ genomic DNA for each sample was conducted using the EZ DNA Methylation Golden kit according to manufacturer instructions (ZYMO Research, California, USA). Bisulfite-converted DNA was eluted in $20 \mu \mathrm{L}$ elution buffer (ZYMO Research).

\section{Hot start PCR and bisulfite cloning sequencing}

PCR primers of porcine $C D 4$ promoter used for DNA methylation assay (NCBI: Gene ID_404704, $-223 \mathrm{bp}$ to $-102 \mathrm{bp}$ from the transcriptional start site) were designed with the Oligo 6.0 software (Table 1). Hot start PCR was carried out in $25 \mu \mathrm{L}$ solution including 15 to 20 ng bisulfite-treated DNA, 12.5 $\mu \mathrm{L}$ Hot start PCR premix (ZYMO Research), $0.5 \mu \mathrm{M}$ forward primer, and $0.5 \mu \mathrm{M}$ reverse primer. PCR cycling conditions were $95^{\circ} \mathrm{C}$ for $10 \mathrm{~min}$, followed by 40 cycles of $94^{\circ} \mathrm{C}$ for $30 \mathrm{~s}, 50$ to $60^{\circ} \mathrm{C}$ for $45 \mathrm{~s}$, and $72^{\circ} \mathrm{C}$ for $45 \mathrm{~s}$, and a final incubation at $72^{\circ} \mathrm{C}$ for $10 \mathrm{~min}$. The PCR products were checked using $2 \%$ agarose gels with ethidium bromide. The PCR products were cloned into the pGM-T vector and sequenced using an ABI 377 automated sequencer. Eight clones were sequenced for each sample.

\begin{tabular}{|c|c|c|c|c|c|}
\hline Gene & Primer name & Sequence & Product type & Product size & Annealing temperature \\
\hline \multirow[t]{2}{*}{ CD4 } & Forward & 5'-TATGGAGGTTTTTAGGTTAGG-3' & DNA & \multirow[t]{2}{*}{$365 \mathrm{bp}$} & \multirow[t]{2}{*}{$60^{\circ} \mathrm{C}$} \\
\hline & Reverse & 5'-СТСААСТСТTAАATACACTCT-3' & (hot start PCR) & & \\
\hline \multirow[t]{2}{*}{$C D 4$} & Forward & 5'-CCTTCTGTTTCTCGCTGGG-3' & cDNA & \multirow{2}{*}{$113 \mathrm{bp}$} & \multirow[t]{2}{*}{$60^{\circ} \mathrm{C}$} \\
\hline & Reverse & 5'-GGCAGGTCTTCTTCTCACTA-3' & (real-time qPCR) & & \\
\hline \multirow[t]{2}{*}{$G A P D H$} & Forward & 5'-ACTCACTCTTCTACCTTTGATGCT-3' & cDNA & \multirow[t]{2}{*}{$100 \mathrm{bp}$} & \multirow[t]{2}{*}{$60^{\circ} \mathrm{C}$} \\
\hline & Reverse & 5'-TGTTGCTGTAGCCAAATTCA-3' & (real-time qPCR) & & \\
\hline
\end{tabular}

\section{Real-time qRT-PCR}

Total RNA was extracted from PK15 cells using the Trizol kit (Invitrogen). Contaminated DNA was cleared by DNAse (Qiagen). The first strand cDNA was synthesized from total RNA (1 $\mu$ g per sample) using SuperScriptTM III Reverse Transcriptase (Invitrogen). Real-time quantitative RT-PCR (qRT-PCR) reactions were performed in $20 \mu \mathrm{L}$ solution with a LightCycler480 SYBR Green I Master (Roche) according to manufacturer instructions. Each reaction was performed in triplicate. The mRNA expression level of the validated genes was normalized against the housekeeping gene GAPDH (glyceraldehyde-3-phosphate dehydrogenase) in 
the corresponding samples. The PCR reactions were cycled 40 times after the initial denaturation $\left(95^{\circ} \mathrm{C}, 5 \mathrm{~min}\right)$ with the following parameters: denaturation at $95^{\circ} \mathrm{C}$ for $15 \mathrm{~s}$, annealing at $60^{\circ} \mathrm{C}$ for $15 \mathrm{~s}$, and extension at $72^{\circ} \mathrm{C}$ for $35 \mathrm{~s}$. The primers are shown in Table 1 .

\section{Electrophoretic mobility shift assay (EMSA)}

Nuclear fractions were extracted from $1.5 \times 10^{7}$ PK15 cells using a cytoplasmnucleoprotein extraction kit (Viagene Biotech, Ningbo, China) and quantified using a BCA protein assay kit (Viagene Biotech). The non-radioactive DNA binding reactions were performed at room temperature with $1.5 \mu \mathrm{g}$ Poly (dI:dC), $2 \mu \mathrm{g}$ nuclear extract, and either $10 \mu \mathrm{g}$ PolyI:C, $5 \mu \mathrm{M}$ AzaCdR or PolyI:C plus Aza-CdR to a final volume of $15 \mu \mathrm{L}$ using the LightShiff ${ }^{\mathbb{B}}$ Chemiluminescent EMSA kit (Pierce, Rockford, IL, USA). The probes used in the EMSA analysis were based on the following porcine $C D 4$ gene promoter sequence (chromosome 5: 59957641-59958171): 30 pmol Ds-Bio-NFkB probe: Bio 5'-CCACAACGGGAACTCCCAAAAAA -3'; 30 pmol DsBio-Met (methylated) - NFkB probe: Bio 5'-CCACAA ${ }^{(\mathrm{CH} 3)}$ CGGGAACTCCCAAAAAA-3'; 30 pmol 100X Ds-Cold-NFkB probe: Cold 5'-CCACAACGGGAACTCCCAAAAAA-3'; 30 pmol 100X Ds-Cold-Met-NFkB probe: Cold 5'-CCACAA ${ }^{(\mathrm{CH} 3)}$ CGGGAACTCCCAAAAAA-3'. Underline represents the NF-kappa motif sequence. The resulting complexes were resolved on a $5 \%$ polyacrylamide gel and exposed to film.

\section{Statistical analysis}

Relative quantification of $C D 4$ expression level compared to $G A P D H$ was performed by a $2^{(-\Delta \Delta C t)}$ method (Livak et al., 2001). The Student $t$-test was used to analyze the differences in the mRNA expression levels of the porcine $C D 4$ gene between the treatments.

\section{RESULTS}

\section{Activation of TLR3 and IFN expression induced by viral-like dsRNA in PK15 cells}

The activation of interferon $\alpha$ (IFN $\alpha$ ) and toll-like receptor 3 (TLR3) induced by viral dsRNA is a significant sign for host immune response to virus replication. To acquire the key time points of synthetic viral-like dsRNA (PolyI:C) transfection, a time-course experiment was performed with PK15 cells. The cells were collected at $0,4,6,8,10$, and $12 \mathrm{~h}$ post-transfection with PolyI:C (Figure 1). Real-time qRT-PCR showed that the transcriptional expressions of TLR3 (2.3-fold) and IFN (2.4-fold) were significantly upregulated in PK15 cells at $10 \mathrm{~h}$ compared to that at $0 \mathrm{~h}(\mathrm{P}<0.05)$. Moreover, IFN $\alpha$ was upregulated $(2.7$-fold $)$ in the early transfection phase $(4 \mathrm{~h}$ post-transfection) compared to that at $0 \mathrm{~h}(\mathrm{P}<0.05)$.

\section{Activation of CD4 induced by PolyI:C in PK15 cells}

To explore the effects of PolyI:C on CD4 gene expression in PK15 cells, the transcriptional expression of the $C D 4$ gene was detected using real-time qRT-PCR. The results indicated that the mRNA expression of $C D 4$ was significantly upregulated as time progressed compared to the untreated cells at $0 \mathrm{~h}(0 \mathrm{~h}$ to $12 \mathrm{~h}, \mathrm{P}<0.05)$, except for the cells at $8 \mathrm{~h}$ post-transfection, 
$\mathrm{P}>0.05$ ) (Figure 2A). Accordingly, the percentage of methylation at the $C D 4$ promoter $\mathrm{CpG}$ sites was significantly decreased in the PolyI:C-transfected PK15 cells (69.4\% at $4 \mathrm{~h}$ and $51.4 \%$ at $10 \mathrm{~h}$ ) compared to the untreated cells $(90.3 \%$ at $0 \mathrm{~h}$ ) (Figure 2B). As shown in Figure 2C, the first $\mathrm{CpG}$ site is overlapped with the predicted binding site of NF- $\kappa \mathrm{B}$ transcriptional factor (TFSEARCH software). These data indicated that PolyI:C induced the demethylation of the $C D 4$ promoter, which may activate the expression of the $C D 4$ gene in the cells.
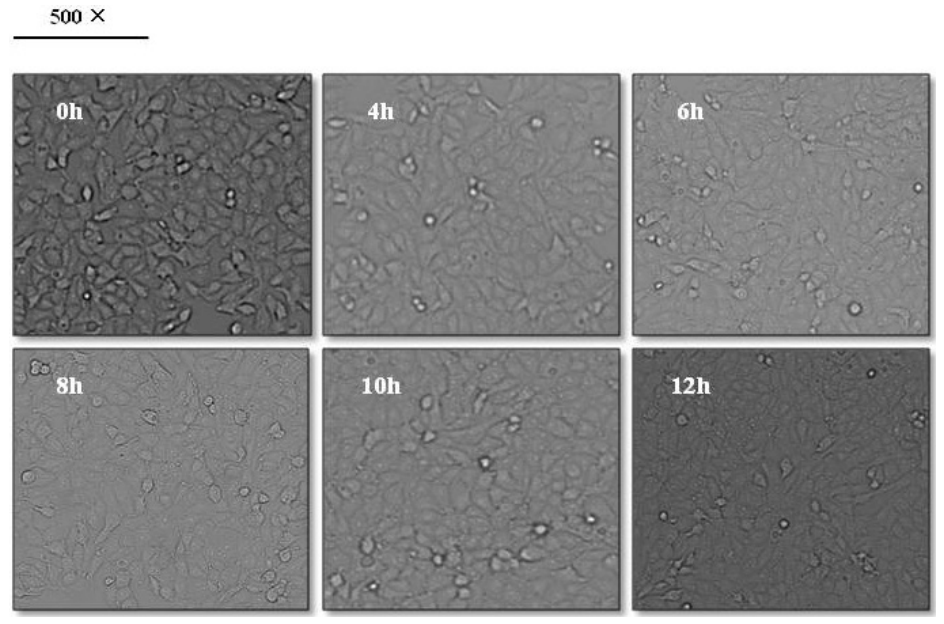

Figure 1. Time-course assay of the PK15 cells at $0,4,6,8,10,12$ h post-treatment with PolyI:C.

$A$

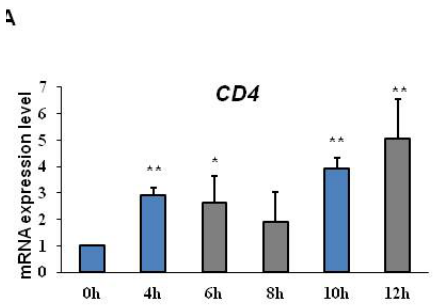

C

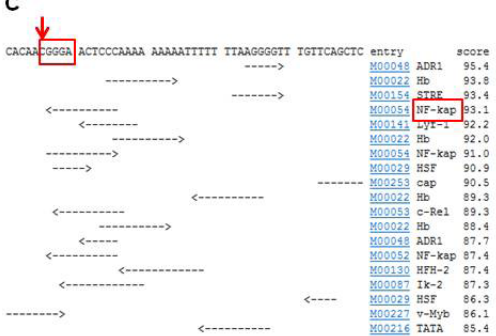

ธ

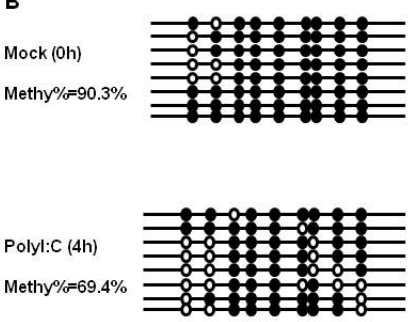

Polyl:C (10h)

Methy $\%=51.4 \%$

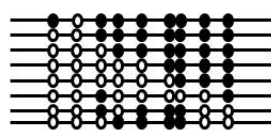

Figure 2. Variation of mRNA expression and DNA methylation of the $C D 4$ gene in PK15 cells treated with PolyI:C at different time points. A. mRNA expression level of $C D 4$ at different time points; $C D 4$ was significantly upregulated at 4, 6,10 , and $12 \mathrm{~h}$ post-treatment; B. Bisulfite clone sequencing of the $C D 4$ promoter region in PK15 cells was conducted at 0, 4, $10 \mathrm{~h}$ post-treated with PolyI:C $(10 \mu \mathrm{g} / \mathrm{mL}$, the blue bars in Figure $2 \mathrm{~A})$; the methylation degree (Methy\%) is shown; C. predicted binding site of NF-карра on porcine CD4 promoter; -223 to $-102 \mathrm{bp} \mathrm{CpG} \mathrm{sites} \mathrm{on} \mathrm{the} \mathrm{upstream} \mathrm{of} \mathrm{the} \mathrm{CD4}$ gene (red arrow) are overlapped with the consensus sequence of NF- $\kappa$ motif (-222 to $-218 \mathrm{bp}$, red box). 


\section{Demethylation of the $C D 4$ promoter and activation of $C D 4$ gene induced by PolyI:C and Aza-CdR}

To determine whether PolyI:C initiates $C D 4$ transcription by demethylation, we further examined the influence of PolyI:C transfection, demethylating agent (Aza-CdR) treatment or both in PK15 cells. In combined treatment, the PK15 cells were initially infected with PolyI:C (10 $\mu \mathrm{g} /$ $\mathrm{mL})$, and Aza-CdR $(5 \mu \mathrm{M})$ was then added after $4 \mathrm{~h}$ of PolyI:C infection. We found that Aza-CdR $(1 \mu \mathrm{M})$ or PolyI:C $(10 \mu \mathrm{g} / \mathrm{mL})$, alone or combined, significantly promoted the expression of the $C D 4$ gene in the cells $(\mathrm{P}<0.05$, Figure $3 \mathrm{~A})$. After adding Aza-CdR $(5 \mu \mathrm{M})$ following treatment with PolyI:C $(10 \mu \mathrm{g} / \mathrm{mL})$, the mRNA expression of $C D 4$ reached its maximal level compared to other concentrations $(\mathrm{P}<0.05)$. However, the treatment of $0.1 \mu \mathrm{M}$ or $5 \mu \mathrm{M}$ Aza-CdR alone did not influence significantly $C D 4$ expression compared to the untreated cells $(\mathrm{P}>0.05$, Figure $3 \mathrm{~A})$.
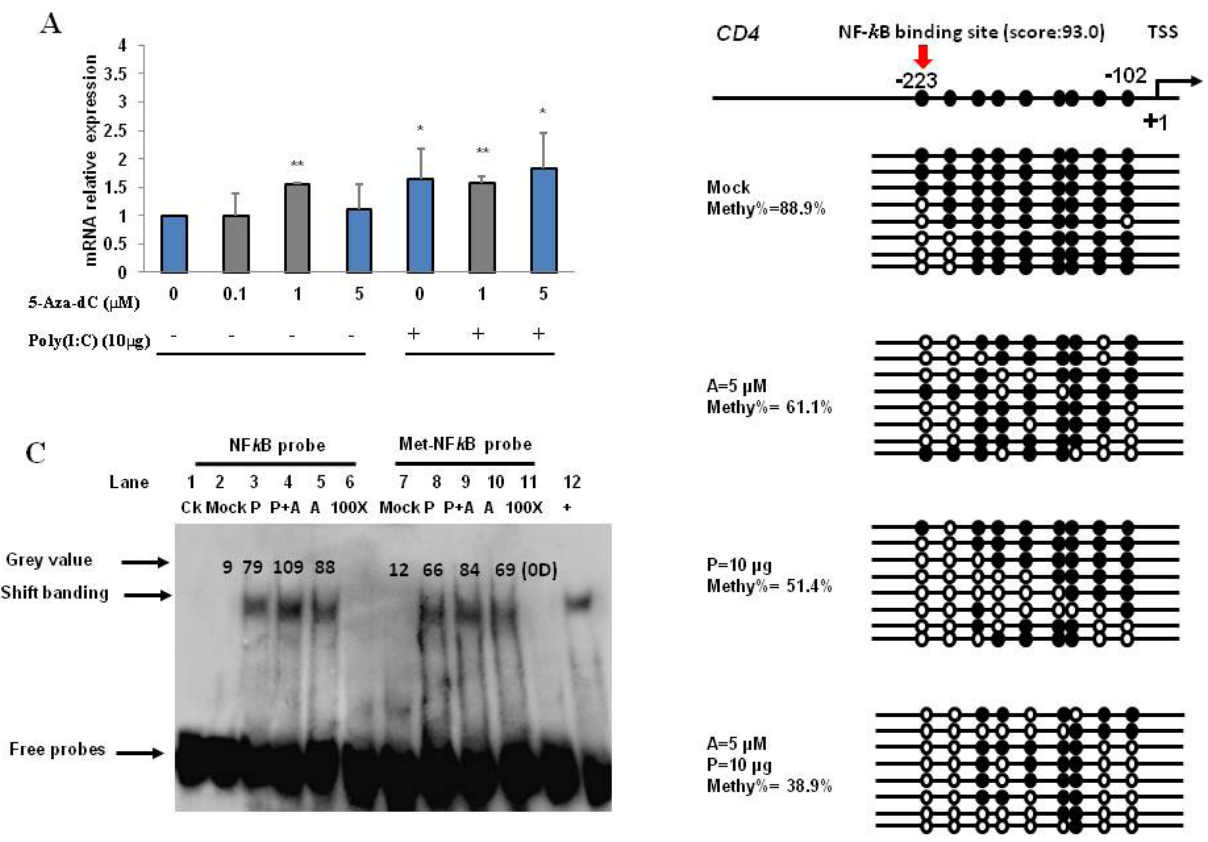

Figure 3. Active mechanism of the porcine $C D 4$ gene in PK15 cells induced by dsRNA and Aza-CdR. A. Doseresponse assay of the porcine $C D 4$ gene with PolyI:C, Aza-CdR, or both. Significant levels were determined using a $t$-test by comparing the expression levels of $C D 4$ between each treatment and the control. $* \mathrm{P}<0.05,{ }^{*} * \mathrm{P}<$ 0.01 . B. Bisulfite cloning sequencing results of the CD4 promoter region in untreated PK15 cells (mock) and the cells treated with Aza-CdR $(5 \mu \mathrm{M})$, PolyI:C $(10 \mu \mathrm{g} / \mathrm{mL})$, or both at $10 \mathrm{~h}$ (the blue bars in Figure $3 \mathrm{~A})$. Open circle, unmethylated $\mathrm{CpG}$ filled; solid circle, methylated $\mathrm{CpG}$ site; red arrow, scoring of trans factor of NF- $\mathrm{K}$ in TFMATRIX entries. The percentages of methylation for the nine CpG sites is shown. C. EMSA results using a

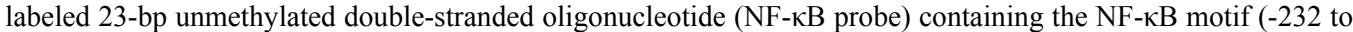
$-223 \mathrm{bp}$ ). The same double-stranded oligonucleotide was methylated in vitro with SAM methyltransferases (Met$\mathrm{NF}-\kappa \mathrm{B}$ probe). Gel shift assays were conducted with nuclear extracts from PK15 cells treated with PolyI:C (P, 10 $\mu \mathrm{g} / \mathrm{mL})$, Aza-CdR $(\mathrm{A}, 5 \mu \mathrm{M})$, or both $(10 \mu \mathrm{g} / \mathrm{mL}$ PolyI:C plus $5 \mu \mathrm{M}$ Aza-CdR, P+A). As competitors, 100-fold unlabeled unmethylated probes (cold NF- $\mathrm{kB}$ ) or methylated probes (cold met-NF- $\mathrm{kB}$ ) are shown in the lane 6 and $11(100 \mathrm{X})$, respectively. $\mathrm{Ck}=$ negative control; $+=$ positive control for NF- $\mathrm{kB}$ (lane 12; EMSA of human acute monocytic leukemia cell line THP-1 that were stimulated with $50 \mathrm{ng} / \mathrm{ml} \mathrm{TNF}$ alpha for $45 \mathrm{~min})$. The grey value is the absorption intensity of the probes, shown with optical density (OD). 
To obtain precise information about DNA methylation variations in the CD4 promoter, high-sensitivity bisulfite sequencing of the promoter region of $C D 4$ was performed. As shown in Figure 3B, the promoter region of CD4 (-223 to $-102 \mathrm{bp}$ from transcriptional start site) contains nine $\mathrm{CpG}$ sites. The bisulfite sequencing results showed that the percentages of methylation in the $C D 4$ promoter $\mathrm{CpG}$ sites were significantly lower in the PolyI:C plus Aza-CdR-treated PK15 cells (38.9\%), in the PolyI:C-transfected cells (51.4\%) and in the Aza-CdR- treated cells (61.1\%) than in the uninfected cells (88.9\%) (Figure 3B). More importantly, the CpG site in the NF- $\kappa$ motif (-223p to $-222 \mathrm{bp}$ ) in the CD4 promoter showed $37.5 \%$ demethylation or $25 \%$ demethylation in response to the PolyI:C plus Aza-CdR transfection or PolyI:C treatment compared to mock treatment, respectively.

\section{Increasing binding of $\mathrm{NF}-\mathrm{kB}$ to $\mathrm{CD} 4$ promoter in response to demethylation}

We then tested the influence of DNA methylation on the affinity of nuclear factor

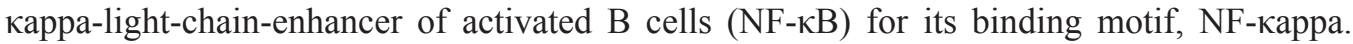
Electrophoretic mobility shift assay (EMSA) was carried out using a NF- $\kappa \mathrm{B}$ probe and the corresponding methylated NF- $\kappa B$ probe. The specificity of NF- $\kappa B$ binding was verified with an unlabeled NF-карpa competitor and an unlabeled methylated NF-карpa competitor (Figure $3 \mathrm{C})$. The results of the EMSA indicated that the methylated $\mathrm{CpG}$ site in the $\mathrm{CD} 4$ promoter reduced the formation of the NF- $\mathrm{KB}$ protein-DNA complex (lanes 8, 9, 10) up to $16.5 \%$ (PolyI:C, lane 3), 23\% (PolyI:C plus Aza-CdR, lane 4), and 21.6\% (Aza-CdR, lane 5) compared to that of the unmethylated CpG site (Figure 3C). These data suggested that PolyI:C and Aza-CdR induced DNA demethylation, which promotes the binding of NF- $\kappa \mathrm{B}$ to the $C D 4$ promoter and activates the expression of $C D 4$.

\section{DISCUSSION}

It is well-known that epigenetic modification plays an important role in the on/off switching of transcriptional regulation in mammals (Allis et al., 2006). In humans and mouse, transcription factor binding sites, including the Myb binding site, Elf binding site, and Ikaros binding site, have been found in the promoter region of CD4 (Ellmeier et al., 1999). In pigs, the binding site of NF- $\kappa$ has been found in the $C D 4$ promoter. The transcription factor NF- $\mathrm{kB}$ is activated by swine fever virus in infected porcine vascular endothelial cells (Bensaude et al., 2004). Our results are the first to reveal the key roles that viral-like dsRNA and DNA methyltransferase inhibitor activate $C D 4$ expression by an epigenetic mechanism through NF- $\mathrm{KB}$ affinity efficiency in epithelial cells.

Cluster of differentiation 4 protein (CD4) plays a key role in T cell-signaling transduction and host resistance during viral infection (Zou et al., 2001; Luo et al., 2011). T lymphocytes that express the $C D 4$ marker, primarily of the $\mathrm{CD}^{+} \mathrm{T}$ lymphocyte phenotype, have been shown to be activated during acute kidney injury (Lie et al., 2012). Recruitment and activation of $\mathrm{CD}^{+} \mathrm{T}$ lymphocytes after kidney injury could be the very important early event that mediates the onset of renal fibrogenesis (Liu et al., 2012). The kidney is one of the target tissues of porcine pseudorabies virus (PRV), Africa swine fever virus (ASFC) and classical swine fever virus (CSFV) (Flori et al., 2008; Sun et al., 2008; Wei and Qing, 2008). In our study, two- to fourfold increase in CD4 expression was observed in the porcine PK15 epithelial cell line 
transfected by PolyI:C. Flori et al. (2008) reported that CD4 was upregulated in PK15 cells after $4 \mathrm{~h}$ post-infection with PRV. Although the observation of $C D 4$ activation in PK15 cell infected by PolyI:C or PRV showed a poor biological significance, the results raise the question concerning the regulation mechanisms of immune-related genes in non-immune cells (Anders, 2007; Flori et al., 2008). Thus, further research is warranted to identify and compare CD4 gene expression regulated by real virus in non-immune and immune cells.

Virus infection normally changes the expression and epigenetic status of immune-related genes. Tang et al. (2011) used PolyI:C to substitute influenza virus infection and focused on the $I L-6$ expression in PolyI:C- or influenza virus-infected human lung epithelial cell line (A549). In the current study, the expression levels of the CD4 gene were upregulated at 4 and $10 \mathrm{~h}$ after viral-like dsRNA transfection, while the methylation status was downregulated in the $C D 4$ promoter. DNA methylation stably alters gene expression in cells so that such cells can remember where they have been and then decrease gene expression. We found that the DNA methylation status of $C D 4$ gene in PK15 cells was stably maintained for at least three passages. Moreover, the methylation fluctuation was observed in whole blood cells and peripheral blood mononuclear cell (PBMCs) of the pigs that were immunized by CSFV antibody (data not shown). These results demonstrated that PolyI:C induced the demethylation of the CD4 promoter in the epithelial cells.

Recently, research concerning DNA methylation mechanisms has focused on the use of Aza-CdR to study the relation of DNA methylation and transcription (Rishi et al., 2010). AzaCdR is DNMTs inhibitor with demethylating effects (Patel et al., 2010). Previous accumulating data suggested that inhibition of DNA methylation was linked to Aza-CdR dose-dependent treatment in human epithelial cells, which correlated with the disruption of the DNMT1 gene (Karpf et al., 2004). The microarray analysis showed that Aza-CdR inhibited DNMT3a expression in the PK15 cells (Wang et al., 2013). In the current study, we found that the CD4 gene was $27 \%$ demethylated with $5 \mu \mathrm{M}$ Aza-CdR alone and around $50 \%$ demethylated with $5 \mu \mathrm{M}$ Aza-CdR combined with $10 \mu \mathrm{g}$ PolyI:C transfection compared to control cells (Figure 3). Although there was a significant decrease in $C D 4$ promoter methylation and NF-kB binding in corresponding cells ( $5 \mu \mathrm{M}$ Aza-CdR treatment, $\mathrm{P}<0.01)$, this did not significantly alter $C D 4$ expression $(\mathrm{P}=$ 0.1 ) (Figure $3 \mathrm{C}$ ). Accordingly, we infer that less than thirty percent alteration in methylation may not significantly influence the expression of the $C D 4$ gene.

EMSA has proven to be a rapid, simple, and sensitive method for the detection of sequence-specific DNA-binding proteins (Adachi et al., 2005). Aza-CdR increased NFkB binding to Fas promoter detected by chromatin immunoprecipitation assay (Wu and Wood, 2011). Here, we found that the DNA demethylation effect of Aza-CdR can upregulate $C D 4$, at least partially via increased $\mathrm{NF}-\kappa \mathrm{B}$ transcription factor binding. Our research provides a novel approach to study the hypomethylation of epithelial cells transfected by dsRNA combined with Aza-CdR.

In summary, the hypomethylation of porcine CD4 promoter and the demethylation of its NF- $\kappa B$ binding site induced by PolyI:C and Aza-CdR improve the transcription level of the $C D 4$ gene in porcine PK15 cells. These findings are of benefit to clarify the regulatory mechanism of DNA methylation in epithelial cells in response to virus infection.

\section{ACKNOWLEDGMENTS}

Research supported by the Innovation Research Team for Modern Agricultural Indus- 
try and Technology in Beijing City (\#25019126), Twelfth Five-Year Plan for National Science and Technology Projects in Rural Areas (\#2011BAD28B01), Project for Science and Technological Innovation of Yunnan Province (\#2010AB001), Program for New Breed Development using Transgenic Technology (\#2009ZX08009-146B and \#2013ZX08011-006), and Program for Changjiang Scholars and Innovative Research Team in University (\#IRT1191). We thank the China Center for Type Culture Collection for providing the porcine kidney cell line (\#PK15).

\section{REFERENCES}

Adachi Y, Chen W, Shang WH and Kamata T (2005). Development of a direct and sensitive detection method for DNAbinding proteins based on electrophoretic mobility shift assay and iodoacetamide derivative labeling. Anal. Biochem. 342: 348-351.

Allis CD, Jenuwein T, Reinberg D and Caparros ML (2006). Epigenetics. Cold Spring Harbor Laboratory Press, New York.

Anders HJ (2007). Innate pathogen recognition in the kidney: toll-like receptors, NOD-like receptors, and RIG-like helicases. Kidney Int. 72: 1051-1056.

Bauhofer O, Summerfield A, McCullough KC and Ruggli N (2005). Role of double-stranded RNA and Npro of classical swine fever virus in the activation of monocyte-derived dendritic cells. Virology 343: 93-105.

Bensaude E, Turner JL, Wakeley PR, Sweetman DA, et al. (2004). Classical swine fever virus induces proinflammatory cytokines and tissue factor expression and inhibits apoptosis and interferon synthesis during the establishment of long-term infection of porcine vascular endothelial cells. J. Gen. Virol. 85: 1029-1037.

de La Motte CA, Hascall VC, Calabro A, Yen-Lieberman B, et al. (1999). Mononuclear leukocytes preferentially bind via CD44 to hyaluronan on human intestinal mucosal smooth muscle cells after virus infection or treatment with poly (I.C). J. Biol. Chem. 274: 30747-30755.

Ellmeier W, Sawada S and Littman DR (1999). The regulation of CD4 and CD8 coreceptor gene expression during T cell development. Annu. Rev. Immunol. 17: 523-554.

Flanagan JM (2007). Host epigenetic modifications by oncogenic viruses. Br. J. Cancer 96: 183-188.

Flori L, Rogel-Gaillard C, Cochet M, Lemonnier G, et al. (2008). Transcriptomic analysis of the dialogue between pseudorabies virus and porcine epithelial cells during infection. BMC Genomics 9: 123.

Geiss G, Jin G, Guo J, Bumgarner R, et al. (2001). A comprehensive view of regulation of gene expression by doublestranded RNA-mediated cell signaling. J. Biol. Chem. 276: 30178-30182.

Gladue DP, Zhu J, Holinka LG, Fernandez-Sainz I, et al. (2010). Patterns of gene expression in swine macrophages infected with classical swine fever virus detected by microarray. Virus Res. 151: 10-18.

Harris P, Sridhar S, Peng R, Phillips JE, et al. (2013). Double-stranded RNA induces molecular and inflammatory signatures that are directly relevant to COPD. Mucosal Immunol. 6: 474-484.

Heitmeier MR, Scarim AL and Corbett JA (1998). Double-stranded RNA-induced inducible nitric-oxide synthase expression and interleukin-1 release by murine macrophages requires NF-kappaB activation. J. Biol. Chem. 273: 15301-15307.

Hüsser L, Alves MP, Ruggli N and Summerfield A (2011). Identification of the role of RIG-I, MDA-5 and TLR3 in sensing RNA viruses in porcine epithelial cells using lentivirus-driven RNA interference. Virus Res. 159: 9-16.

Karpf AR, Lasek AW, Ririe TO, Hanks AN, et al. (2004). Limited gene activation in tumor and normal epithelial cells treated with the DNA methyltransferase inhibitor 5-aza-2'-deoxycytidine. Mol. Pharmacol. 65: 18-27.

Lie ML, White LE, Santora RJ, Park JM, et al. (2012). Lung T lymphocyte trafficking and activation during ischemic acute kidney injury. J. Immunol. 189: 2843-2851.

Liu L, Kou P, Zeng Q, Pei G, et al. (2012). CD4+ T Lymphocytes, especially Th2 cells, contribute to the progress of renal fibrosis. Am. J. Nephrol. 36: 386-396.

Livak KJ and Schmittgen TD (2001). Analysis of relative gene expression data using real-time quantitative PCR and the $2^{-\Delta \Delta C}$ T Method. Methods 25: 402-408.

Luo J, Yu Y, Zhang H, Tian F, et al. (2011). Downregulation of promoter methylation level of CD4 gene after MDV infection in MD-susceptible chicken line. BMC Proc. (Suppl 4):5 S7.

Majde JA (2000). Viral double-stranded RNA, cytokines, and the flu. J. Interferon Cytokine Res. 20: 259-272.

Patel K, Dickson J, Din S, Macleod K, et al. (2010). Targeting of 5-aza-2'-deoxycytidine residues by chromatin-associated DNMT1 induces proteasomal degradation of the free enzyme. Nucleic Acids Res. 38: 4313-4324. 
Rishi V, Bhattacharya P, Chatterjee R, Rozenberg J, et al. (2010). CpG methylation of half-CRE sequences creates C/ EBPalpha binding sites that activate some tissue-specific genes. Proc. Natl. Acad. Sci. U. S. A. 107: 20311-20316.

Stowell NC, Seideman J, Raymond HA, Smalley KA, et al. (2009). Long-term activation of TLR3 by poly (I: C) induces inflammation and impairs lung function in mice. Respir. Res. 10: 43.

Sun J, Jiang Y, Shi Z, Yan Y, et al. (2008). Proteomic alteration of PK-15 cells after infection by classical swine fever virus. J. Proteome Res. 7: 5263-5269.

Tang B, Zhao R, Sun Y, Zhu Y, et al. (2011). Interleukin-6 expression was regulated by epigenetic mechanisms in response to influenza virus infection or dsRNA treatment. Mol. Immunol. 48: 1001-1008.

Tissari J, Siren J, Meri S, Julkunen I, et al. (2005). IFN- $\alpha$ enhances TLR3-mediated antiviral cytokine expression in human endothelial and epithelial cells by upregulating TLR3 expression. J. Immunol. 174: 4289-4294.

Wang X, Ao H, Zhai L, Bai L, et al. (2013). Genome-wide effects of DNA methyltransferase inhibitor on gene expression in double-stranded RNA transfected porcine PK15 cells. Genomics [Epub ahead of print].

Wei P and Qing AJ (2008). Molecular Biology of Important Animal Viruses. Science Press, China, 46-72.

Wu J and Wood GS (2011). Reduction of Fas/CD95 promoter methylation, upregulation of Fas protein, and enhancement of sensitivity to apoptosis in cutaneous T-cell lymphoma. Arch. Dermatol. 147: 443-449.

Zou YR, Sunshine MJ, Taniuchi I, Hatam F, et al. (2001). Epigenetic silencing of CD4 in T cells committed to the cytotoxic lineage. Nat. Genet. 29: 332-336. 